\title{
Aspiration in seriously ill patients: a study of amylase in bronchial secretions
}

\author{
PD CLARKE, BC BAIN, A DAVIES, GE LEVIN, HP LAMBERT \\ From the Departments of Communicable Diseases and Chemical Pathology, St George's Hospital, \\ London SW17
}

SUMMARY Bronchial secretions from 21 patients with moderate to severe chest infections were obtained by transtracheal aspiration. Six seriously ill patients showed greatly increased levels of amylase activity in the bronchial secretions compared with those found in the 15 less ill patients. This amylase was almost certainly derived from oropharyngeal contents and its presence suggests that aspiration may be more common in comatose and semi-comatose patients than is generally appreciated.

Percutaneous transtracheal aspiration (TTA) is a method of collecting bronchial secretions by inserting a needle and cannula through the circothyroid membrane below the larynx. ${ }^{1}$ The specimens obtained are usually uncontaminated as judged by the lack of buccal epithelial cells on microscopy and the purity of bacterial cultures obtained. ${ }^{2}$ To our knowledge amylase activities have not previously

Accepted for publication 29 December 1980 been measured in bronchial secretions to assess the degree of contamination by oral contents.

\section{Patients and methods}

Twenty-one patients were studied as part of a larger project to evaluate the use of transtracheal aspiration (TTA) in the management of difficult chest infections in a general hospital. All were moderately or severely ill with chest infections (Table). Four of the

Amylase estimations in serum, transtracheal aspirate (TTA) and expectorated sputum (ES) in patients with severe and moderate chest infections

\begin{tabular}{|c|c|c|c|c|c|}
\hline $\begin{array}{l}\text { Serum amylase } \\
\text { IU } / l\end{array}$ & $\begin{array}{l}\text { TTA amylase } \\
\text { IU/l }\end{array}$ & $\begin{array}{l}\text { ES amylase } \\
I U / l\end{array}$ & Diagnosis & Grade of illness & $T T A$ examination organisms isolated \\
\hline $\begin{array}{r}163 \\
187 \\
197 \\
145 \\
75\end{array}$ & $\begin{array}{rl}78 & 000 \\
& \\
56 & 370 \\
8 & 100 \\
10390 \\
4410 \\
145300^{*}\end{array}$ & $\begin{array}{l}621500 \\
\text { NA } \\
\text { NA } \\
74700 \\
255300 \\
56800\end{array}$ & $\begin{array}{l}\text { Pneumonia } \\
\text { Pneumonia } \\
\text { Pneumonia } \\
\text { Pneumonia } \\
\text { Pneumonia } \\
\text { Pneumonia }\end{array}$ & SEVERE & $\begin{array}{l}\text { Strep pneumoniae, Strep pyogenes, Staph albus, } \\
\quad \text { Neisseria sp } \\
\text { Klebsiella pneumoniae, Candida sp } \\
\text { Staph aureus } \\
\text { Strep pneumoniae, H influenzae } \\
\text { Strep pneumoniae, H influenzae } \\
\text { Strep pneumoniae, } H \text { influenzae, Strep viridans }\end{array}$ \\
\hline $\begin{array}{r}615 \\
85 \\
306 \\
137 \\
380 \\
125 \\
236 \\
274 \\
305 \\
425 \\
344 \\
\text { NA } \\
\text { NA } \\
359 \\
152\end{array}$ & $\begin{array}{ll} & 620 \\
4 & 470 \\
3 & 590 \\
700^{*} \\
1 & 200^{*} \\
1 & 370 \\
1 & 300 \\
2 & 390 \\
& 540 \\
2 & 250^{*} \\
& 450 \\
& 740 \\
& 970 \\
2 & 600 \\
& 330^{*}\end{array}$ & $\begin{aligned} 98900 \\
115000 \\
109700 \\
91500 \\
250000 \\
11100 \\
52000 \\
148600 \\
362000 \\
\text { NA } \\
273700 \\
61500 \\
217500 \\
140900 \\
\text { NA }\end{aligned}$ & $\begin{array}{l}\text { Pneumonia } \\
\text { Chr bronchitis } \\
\text { Chr bronchitis } \\
\text { Chr bronchitis } \\
\text { Chr bronchitis } \\
\text { Chr bronchitis } \\
\text { Pneumonia } \\
\text { Chr bronchitis } \\
\text { Bronchiectasis } \\
\text { Pneumonia } \\
\text { Lung abscess } \\
\text { Chr bronchitis } \\
\text { Chr bronchitis } \\
\text { Chr bronchitis } \\
\text { Pneumonia }\end{array}$ & MODERATE & $\begin{array}{l}\text { Proteus sp } \\
\text { H influenzae } \\
\text { Pseudomonas } \mathrm{sp} \\
\text { Nil } \\
\text { Nil } \\
\text { Strep pneumoniae, H parainfluenzae } \\
\text { Nil } \\
\text { H influenzae } \\
\text { H influenzae } \\
\text { E coli, Pseudomonas } \mathrm{sp} \\
\text { H influenzae, Bacteroides } \mathrm{sp} \\
\text { B catarrhalis } \\
\text { Strep pyogenes, H parainfluenzae } \\
\text { B catarrhalis } \\
\text { Nil }\end{array}$ \\
\hline
\end{tabular}


six seriously ill patients were semi-comatose and had received pharyngeal suction on the Intensive Care Unit, although none had been intubated. The 15 less ill patients were fully conscious and had not received oral hygiene.

TTA was carried out in the standard manner described by Pecora ${ }^{1}$ with only minor modifications. Droperidol was administered intravenously in a dose of 2-10 mg to some alert patients as premedication, but never in sufficient dose to affect consciousness. In five patients (see Table) a small volume of normal saline was introduced into the trachea via the cannula to facilitate sampling. Expectorated sputum (ES) was collected either immediately before or during the TTA procedure in alert patients, but pharyngeal suction specimens were used in some of the seriously ill. Specimens were stored at $+4^{\circ} \mathrm{C}$ for a variable period of up to three weeks before estimation of the amylase activities. Sera taken at the time of the procedure were stored at $-20^{\circ} \mathrm{C}$ for similar periods before analysis.

Amylase activities in ES, TTA samples, and serum were estimated by hydrolysis of a water insoluble blue starch polymer with the Phadebas amylase test kit (Pharmacia Diagnostics). The specimens were diluted and homogenised with dithro-threitol (Sputolysin) which allows dissolution of the mucus and was shown not to affect amylase activity. Particulate matter was removed by centrifugation. The reproducibility of this method for estimating amylase in sputum and tracheal aspirate is poor, due partly to the lack of homogeneity of the samples, and partly to the difficulty of pipetting viscous material, with a coefficient of variability of $27 \%$ on nine paired samples.

Bacteriological methods, to be reported in detail elsewhere, included Gram-stain examination as well as culture, and counterimmunoelectrophoresis.

\section{Results}

Amylase activities in serum, TTA and ES are listed with the bacteriological and microscopic findings in the Table. In seriously ill patients the mean TTA amylase activity was $50000 \mathrm{IU} / 1$ while in the less ill patients it was $1565 \mathrm{IU} / 1(\mathrm{p}<0.0005)$. The mean ES amylase activity was $206000 \mathrm{IU} / \mathrm{l}$. The mean serum amylase activity was $260 \mathrm{IU} / \mathrm{l}$.

\section{Discussion}

In our study, the activities of amylase in the TTA samples of the less ill, alert patients were significantly higher than serum activities. Lung tissue, however, is known to contain amylase at a higher concentration than serum ${ }^{3}$ and at levels compatible with our results so that the difference in amylase activities between the TTA and serum samples do not necessarily imply contamination by oropharyn geal sections. The very high activity seen in the comatose patients, however, cannot be accounted for in this way and is highly suggestive of aspiration. The bacteriological findings are to be discussed in detaip? elsewhere, but it is noteworthy that more than tw bacterial species were found on only three occasions each of them in the seriously ill patients. Multiple isolations are common when aspiration has occurred.

The seriously ill patients had all undergone $\vec{e}$ pharyngeal suction and nasogastric intubation ag routine nursing procedures whilst in the Intensive Care Unit and these procedures might have en couraged aspiration leading to the high levels of amylase activity found in their TTA samples ${ }_{c 0}$ Patient 9 who did not undergo such procedures alse had high activities, however, suggesting thad aspiration may occur in unconscious people without. additional factors. The relevance of our findings to semicomatose and seriously ill patients without ches infections is not known, as we did not feel ethicall justified in including such patients in this study.

Two conclusions can be drawn from this study, First, that although TTA is a valuable diagnostio method in difficult pulmonary infections, contamins ation by oropharyngeal flora is not uncommon an will cause difficulties of interpretation. This limitå tion of TTA has also been noted in a comparison of sputum, TTA and lung aspirates by Davidson et al. and the frequency of contamination by pharyngea contents established by the use of methods such as tracer organism ${ }^{5}$ or methylene blue. ${ }^{6}$ Second, these findings serve as a reminder of the frequency and importance of aspiration in seriously ill patients Even in normal people, aspiration is evident common enough, since bronchograms can bi demonstrated in healthy volunteers after instillation of lipiodol into their noses while asleep. ${ }^{7}$ Aspiratio during anaesthesia is also frequently found in studies using marker dyes. ${ }^{8}$ Nevertheless, cultur of TTA samples from healthy volunteers are usuall sterile, suggesting that oropharyngeal contaminatiow in these subjects does not occur, or that clearanco mechanisms are very efficient. ${ }^{9}$ By contrast, aspiras tion is a common, potentially serious, and undef recognised event in seriously ill patients.

\section{References}

1 Pecora DV. A method of screening uncontaminated tracheal secretion. Journal of Thoracic Surgery 1959;3疋. 653-4.

2 Ries K, Levinson ME, Kaye D. Transtracheal aspiration pulmonary infection. Arch Intern Med 1974;133:453-8. $\frac{\sigma}{\sigma}$

3 Berk JE, Shimamura J, Fridhandler L. Amylase changes 
disorders of the lung. Gastroenterology 1978;74:1313-7.

${ }^{4}$ Davidson M, Tempest B, Palmer DL. Bacteriologic diagnosis of acute pneumonia. JAMA 1976;235:158-63.

${ }^{5}$ Schreiner A, Digranes A, Myking O, Solbert CO. Wert der transtrachealen Aspiration bei bronchopulmonalen Infektionen im Erwachsenenalter. Infection 1973;1:137-43.

${ }^{6}$ Irwin RS, Demers RR, Pratter MR, Erickson AD, Farrugia $R$, Teplitz C. Evaluation of methylene blue and squamous epithelial cells as oropharyngeal markers: a means of identifying oropharyngeal contamination during transtracheal aspiration. J Infect Dis 1980;141:165-71.

${ }^{7}$ Quinn LH, Meyer OO. The relationship of sinusitis and bronchiectasis. Arch Otorhinolaryngol 1929;10:152-65.

8 Berson W, Adriani J. "Silent" regurgitation and aspiration during anesthesia. Anesthesiology 1954;15:644-9.

- Kalinska RW, Parker RA, Borrell D, Hoeprich PD. Diagnostic usefulness and safety of transtracheal aspiration. N Engl J Med 1967;276:604-8.

Requests for reprints to: Professor HP Lambert, Communicable Diseases Unit, St George's Hospital, Blackshaw Road, London SW17 0QT, England.

\section{Reports and Bulletins prepared by the Association of Clinical Biochemists}

The following reports and bulletins are published by the Association of Clinical Biochemists. They may be obtained from The Publishing Department, British Medical Journal (ACB Technical Bulletins), BMA House, Tavistock Square, London WC1H 9JR. Overseas readers should remit by British Postal or Money Order.

SCIENTIFIC REVIEWS (price $£ 1 \cdot 00 / \$ 2.00$ each)

1 The assessment of thyroid function March 1971 FV FLYNN and JR HOBBS

2 Renal function tests suitable for clinical practice January 1972 FL MITCHELL, N VEALL, and RWE WATTS

3 Biochemical tests for the assessment of fetoplacental function May 1975 CE WILDE and RE OAKEY

4 Test of exocrine pancreatic function March 1977 AH GOWENLOCK

5 Assay of cholinesterase in clinical chemistry March 1979 ELSIE SILK, J KING, and MARY WHITTAKER

\section{TECHNICAL BULLETINS (price $£ 1 \cdot 00 / \$ 2.00$ each)}

22 Bilirubin standards and the determination of bilirubin by manual and technicon AutoAnalyzer methods January 1971 BARBARA BILLING, RUTH HASLAM, and N WALD

23 Interchangeable cells for spectrophotometers and fluorimeters September 1971 ss BROWN and AH GOWENLOCK

24 Simple tests to detect poisons March 1972 BW MEADE et al.

25 Blood gas analysers May 1972 K DIXON

26 Kits for enzyme activity determination September 1972 SB ROSALKI and D TARLOW

27 Assessment of pumps suitable for incorporation into existing continuous flow analytical systems November 1972 A FLECK et al.

28 Routine clinical measurements of transferrin in human serum September 1973 K DIXON
29 Control materials for clinical biochemistry (5th edition) September 1973 JF STEVENS

30 Notes on the quality of performance of serum cholesterol assays September 1973 ss BROWN

31 Determination of uric acid in blood and in urine July 1974 RWE WATTS

32 A survey of amino acid analysers readily available in the United Kingdom September 1974 JE CARLYLE and P PURKISS

33 Definitions of some words and terms used in automated analysis November 1974 A FLECK, R ROBINSON, SS BROWN, and JR HOBBS

34 Measurement of albumin in the sera of patients January 1975 LINDA SLATER, PM CARTER, and JR HOBBS 35 Investigation of the validity of temperature correction factors for serum aspartate and alanine transaminases March 1975 SB ROSALKI et al.

36 Factors influencing the assay of creatinine November 1975 JGH COOK

37 A survey of enzyme reaction rate analysers readily available in the United Kingdom July 1977 RA SAUNDERS and RF BURNS

38 Transport of specimens for clinical chemistry analysis November 1977 P WILDING, JF ZILVA, and CE WILDE

39 A scheme for the evaluation of diagnostic kits May 1978 PH LLOYD

40 A practical guide to gamma-counting in radioimmunoassay January 1980 CE WILDE and D OTTEWELL 41 The use of biochemical tests in the diagnosis of disorders of calcium metabolism July 1980 ANGELA FAIRNEY 